\title{
Phytochemicals and biological activities of Macaranga hosei and Macaranga constricta (Euphorbiaceae)
}

Wan Mohd Nuzul Hakimi Wan SALLEH, Nur Zawani Abdul RAZAK, Farediah AHMAD

\begin{abstract}
Phytochemicals and biological activities of the leaves of Macaranga hosei and Macaranga constricta have been studied. Fractionation and purification of the extracts of $M$. hose afforded two triterpenoids, lupenone (1) and $\beta$-sitostenone (2) and two flavonoids, 5-hydroxy-7,4'-dimethoxyflavone (3) and 5-hydroxy-6,7,4'-trimethoxyflavone (4). Three triterpenoids characterized as taraxerone (5), taraxerol (6) and $\beta$-amyrin (7) were isolated from $M$. constricta. The structures of these compounds were established by analysis of their spectroscopic data, as compared to that of reported compounds. Biological activities which include antibacterial, a-glucosidase inhibition and antioxidant were also carried out. The antibacterial activities have demonstrated that all extracts and isolated compounds exhibited weak inhibition against the tested bacterial strains with MIC value exceeded
\end{abstract}

$500 \mu \mathrm{g} / \mathrm{mL}$. Evaluation of $\alpha$-glucosidase inhibition activity using $\rho$-nitrophenyl- $\rho$-D-glucopyranosidase on extracts exhibited $\alpha$-glucosidase inhibitory potential. The most potent a-glucosidase activity was exhibited by the petroleum ether extract of $M$. hosei with inhibitory concentration at $50 \%\left(\mathrm{IC}_{50}\right)$ of $25.3 \mathrm{ppm}$ compared with quercetin (4.5 ppm) and acarbose (12.6 ppm). The antioxidant activity was conducted through DPPH radical scavenging activity and total phenolic content. All the extracts displayed positive results and the methanol extract of $M$. hosei displayed the highest scavenging activity with scavenging concentration at $50 \%\left(\mathrm{SC}_{50}\right)$ value of $25.8 \mathrm{ppm}$. The methanol extract of $M$. hosei also gave the highest total phenol content with $347.7 \mathrm{mg} \mathrm{GAE} / \mathrm{g}$.

Key words: Macaranga hosei; Macaranga constricta; antibacterial; a-glucosidase; antioxidant
Wan Mohd Nuzul Hakimi Wan Salleh

Department of Chemistry, Faculty of Science and Mathematics, Universiti Pendidikan Sultan Idris (UPSI), 35900 Tanjong Malim, Perak, Malaysia

Nur Zawani Abdul Razak, Farediah Ahmad

Department of Chemistry, Faculty of Science, Universiti Teknologi Malaysia (UTM), 81310 Johor Bahru, Johor, Malaysia

Corresponding Author:

Wan Mohd Nuzul Hakimi Wan Salleh

e-mail:wmnhakimi@fsmt.upsi.edu.my

Submitted / Gönderilme: 10.05.2017 Revised / Düzeltme: 22.06.2017 Accepted / Kabul: 07.07.2017

How to cite this article: Salleh WMNHW, Razak NZA, Ahmad F. Phytochemicals and biological activities of Macaranga hosei and Macaranga constricta (Euphorbiaceae). Marmara Pharm J 2017; 21 (4): 881-888

\section{Introduction}

Plants of Macaranga genus is the only genus in the subtribe Macaranginae with over 300 species. This genus is commonly grown in secondary forest and newly cleared areas and distributed in tropical Africa, Madagascar, centered in South-East Asia, Australia and the Pacific regions [12]. Approximately, 40 species are reported to be found in Malaysia's secondary forest [2]. The species of the genus ranging from shade tolerant understory shrubs and small trees to light demanding pioneers [3]. Among the species reported in Malaysia, nine of them are myrmecophytes or mutualistics ant-plants [4-5]. This symbiosis relationship occurs when the plants provide housing or shelter and also food for specific ants in exchange for the protection from herbivorous insects [4]. Two Macaranga species have been selected for the current phytochemical investigation namely M. hosei King ex. Hook.f. and M. constricta Whitmore \& Airy Shaw. 
Macaranga hosei is a large tree that can grow up to 20 to $30 \mathrm{~m}$ tall with a bluishgreen appearance. It is distributed in Peninsular Thailand, Peninsular Malaysia, Sumatra and Borneo and commonly recognized as an early successional tree in lowland areas. The twigs of this plant are becoming hollow due to ant colonization [6]. This myrmechophytic species also have huge, alternate yet simple leaves with three or more veins on it. Macaranga constricta is distributed in Peninsular Malaysia specifically in northeast of Gunung Benom, Pahang [7]. It is a dull grayish-green tree which can grow up to 27 metre tall and can be found in the middle of lowland rain-forest canopy on the hillsides [6-7]. This myrmechophytic species can be recognized by its secondary veins which are strongly encircle and the swelling parts of the twigs become narrower when dry while the complete male flower part of the plant usually have smooth and even surface [8].

Plant species of genus Macaranga have been used as traditional medicines to treat fungal infections, stomachaches, reduce fever, coughs and tonsillitis. This medicinal uses highlight the need to study the phytochemicals and biological activities of M. hosei and M. constricta before the extinction of these species due to deforestation for rural development. Among the species only $M$. hosei have been studied and reported. Isoprenylated flavanones were reported from $M$. hosei collected from Kalimantan, Indonesia [9]. No phytochemicals or biological activities have been reported from M. constricta. This research will provide database of phytochemicals and bioactivities of two Macaranga species. The findings obtained from this research would contribute to the fields of medicine and development of nutraceutical product.

\section{Results and Discussion}

The medicinal values possessed by plant of Macaranga genus have led to phytochemical studies by many researchers. It has been reported that hundreds of secondary metabolites have been successfully isolated. In this study, phytochemical investigation on the leaves of two Macaranga species has been investigated. Four compounds have been isolated from $M$. hosei which are lupenone (1) [10], $\beta$-sitostenone (2) [11], 5-hydroxy-7,4'-dimethoxyflavone (3) [12], and 5-hydroxy6,7,4'-trimethoxyflavone (4) [13]. In addition, taraxerone (5) [14], taraxerol (6) [15], and $\beta$-amyrin (7) [16] have been isolated from $M$. constricta. These metabolites were identified by analysing their spectroscopic data and comparing them with the literature data. Only one phytochemical study on $M$. hosei has been reported previously. Two isoprenylated flavanones namely 4'-O-methyl-8-isoprenylnaringenin and lonchocarpol A have been isolated from the methanol extract of the leaves of $M$. hosei, collected from Indonesia [9]. The current phytochemical investigation provided different metabolites from the species of Indonesia. Flavonoids also have been isolated previously from various Macaranga species such as $M$. tanarius [17], $M$. triloba [18], $M$. indica [19], M. vedeliana [20], M. denticulate [21], and M. kurzii [22].

Lupenone (1) - White solid (2.0 mg, 5.4\%); m.p. $164-166^{\circ} \mathrm{C}$; IR $r_{\max } \mathrm{cm}^{-1}: 2916,1714,1679 ;{ }^{1} \mathrm{H}$ NMR (400 MHz, $\left.\mathrm{CDCl}_{3}\right)$ : $\delta 4.60(1 \mathrm{H}, \mathrm{d}, J=2.4 \mathrm{~Hz}, \mathrm{H}-29 \mathrm{a}), 4.72(1 \mathrm{H}, \mathrm{d}, J=2.4 \mathrm{~Hz}$, $\mathrm{H}-29 \beta), 2.80$ (1H, m, H-19), 2.30 (2H, m, H-21), 1.40-2.00 $(22 \mathrm{H}, \quad \mathrm{m}, \quad \mathrm{H}-1 / \mathrm{H}-2 / \mathrm{H}-5 / \mathrm{H}-6 / \mathrm{H}-7 / \mathrm{H}-9 / \mathrm{H}-11 / \mathrm{H}-12 / \mathrm{H}-13 /$ H-15/H-16/H-18/H-19/H-22), 1.27 (12H, s, H-24/H-23/H26/H-30), 1.17 (3H, s H-25), 0.93 (3H, s, H-27), 0.83 (3H, s H-28); GC-MS: $m / z 424$ [10].

$\beta$-Sitostenone (2) - Colourless solid (43.4 mg, 8.7\%); m.p. 95$97^{\circ} \mathrm{C}$; IR $\mathrm{r}_{\max } \mathrm{cm}^{-1}: 2926,1715,1658 ;{ }^{1} \mathrm{H}$ NMR $(400 \mathrm{MHz}$, $\left.\mathrm{CDCl}_{3}\right): \delta 5.75(1 \mathrm{H}, \mathrm{s}, \mathrm{H}-6), 1.00-2.40(29 \mathrm{H}, \mathrm{m}, \mathrm{H}-1 / \mathrm{H}-2 /$ $\mathrm{H}-4 / \mathrm{H}-7 / \mathrm{H}-8 / \mathrm{H}-9 / \mathrm{H}-11 / \mathrm{H}-12 / \mathrm{H}-14 / \mathrm{H}-15 / \mathrm{H}-16 / \mathrm{H}-17 / \mathrm{H}-$ 20/H-22/H-23/H-24/H-25/H-28), 0.90 (H-19), 0.89 (H-29), 0.87 (H-27), 0.84 (H-26), 0.82 (H-21), 0.73 (H-18); GC-MS: $\mathrm{m} / z 412$ [11].

5-Hydroxy-7,4'-dimethoxyflavone (3) - Yellow solid (1.9 mg, 11.7\%); m.p. 252-254 ${ }^{\circ} \mathrm{C}$; IR r $_{\text {max }} \mathrm{cm}^{-1}: 3298,1659,1594,1502$, $1115 ;{ }^{1} \mathrm{H} \mathrm{NMR}\left(400 \mathrm{MHz}, \mathrm{CDCl}_{3}\right): \delta 11.77(1 \mathrm{H}, \mathrm{s}, \mathrm{H}-5), 8.20$ $\left(2 \mathrm{H}, \mathrm{d}, J=9.20 \mathrm{~Hz}, \mathrm{H}-2^{\prime} / \mathrm{H}-6^{\prime}\right), 7.06(2 \mathrm{H}, \mathrm{d}, J=9.20 \mathrm{~Hz}$, H-3'/H-5'), $6.64(1 \mathrm{H}, \mathrm{s}, \mathrm{H}-3), 6.58(1 \mathrm{H}, \mathrm{d}, J=2.40 \mathrm{~Hz}, \mathrm{H}-6)$, $6.40(1 \mathrm{H}, \mathrm{d}, J=2.40 \mathrm{~Hz}, \mathrm{H}-8), 3.90\left(6 \mathrm{H}, \mathrm{s}, 2 \times \mathrm{OCH}_{3}\right)$; EIMS: $\mathrm{m} / z 298$ [12].

5-Hydroxy-6,7,4'-trimethoxyflavone (4) - Yellow solid (2.0 mg, 5.4\%); m.p. $280-282^{\circ} \mathrm{C}$; IR $\mathrm{r}_{\max } \mathrm{cm}^{-1}$ : 3334, 1649, 1602, 1504, 1217; ${ }^{1} \mathrm{H}$ NMR $\left(400 \mathrm{MHz}, \mathrm{CDCl}_{3}\right): \delta 12.69(1 \mathrm{H}, \mathrm{s}$, H-5), $8.10\left(2 \mathrm{H}, \mathrm{d}, J=9.20 \mathrm{~Hz}, \mathrm{H}-2^{\prime} / \mathrm{H}-6^{\prime}\right), 7.06(2 \mathrm{H}, \mathrm{d}, J=$ $\left.9.20 \mathrm{~Hz}, \mathrm{H}-3^{\prime} / \mathrm{H}-5^{\prime}\right), 6.48$ (1H, s, H-3), 6.38 (1H, s, H-8), 3.90 $\left(9 \mathrm{H}, \mathrm{s}, 3 \times \mathrm{OCH}_{3}\right)$; EIMS: $m / z 328$ [13].

Taraxerone (5) - White solid (0.14 g, 67.5\%); m.p. $240-242^{\circ} \mathrm{C}$; IR $\mathrm{V}_{\text {max }} \mathrm{cm}^{-1}: 2934,1708,1641 ;{ }^{1} \mathrm{H}$ NMR $\left(400 \mathrm{MHz}, \mathrm{CDCl}_{3}\right): \delta$ $5.58(1 \mathrm{H}, \mathrm{dd}, J=3.6,8.4 \mathrm{~Hz}, \mathrm{H}-15), 2.60(1 \mathrm{H}, \mathrm{m}, \mathrm{H}-2 \beta), 2.35$ $(1 \mathrm{H}, \mathrm{ddd}, J=3.6,6.4,16.0 \mathrm{~Hz}, \mathrm{H}-2 \alpha), 2.10(1 \mathrm{H}, \mathrm{dt}, J=3.6$, $13.2 \mathrm{~Hz}, \mathrm{H}-19 \beta), 1.94(1 \mathrm{H}, \mathrm{dd}, J=3.2,15.2 \mathrm{~Hz}, \mathrm{H}-16 \beta), 1.25-$ 1.72 (21H, m, H-1/H-5/H-6/H-7/H-9/H-11/H-12/H-16a/H18/H-19 a/H-21/H-22), 1.16 (3H, s, H-27), 1.10 (9H, s, H-23/ $\mathrm{H}-25 / \mathrm{H}-24), 0.98$ (3H, s, H-29), 0.93 (6H, s, H-28/H-30), 0.85 (3H, s, H-26); GC-MS: $m / z 424$ [14]. 
Taraxerol (6) - White solid (26.6 mg, 2.2\%); m.p. 276-278 ${ }^{\circ} \mathrm{C}$; IR $r_{\max } \mathrm{cm}^{-1}: 3444,2928,1632,1233 ;{ }^{1} \mathrm{H}$ NMR $(400 \mathrm{MHz}$, $\left.\mathrm{CDCl}_{3}\right): \delta 5.56(1 \mathrm{H}, \mathrm{dd}, J=3.2,8.4 \mathrm{~Hz}, \mathrm{H}-15), 3.22(1 \mathrm{H}, \mathrm{dd}$, $J=4.8$ and $11.2 \mathrm{~Hz}, \mathrm{H}-3), 2.05$ (1H, m, H-19ß), $1.94(1 \mathrm{H}, \mathrm{dd}$, $J=3.2$ and $14.8 \mathrm{~Hz}, \mathrm{H}-16 \beta), 1.60(21 \mathrm{H}, \mathrm{m}, \mathrm{H}-2, \mathrm{H}-7, \mathrm{H}-16 \alpha$, H-1/H-11/H-6/H-18/H-22/H-19a/H-12/H-21), 1.11 (3H, s, $\mathrm{H}-27), 1.00$ (3H, s, H-23), 0.97 (3H, s, H-29), 0.95 (3H, s, $\mathrm{H}-24), 0.93$ (3H, s, H-26), 0.90 (3H, s, H-30), 0.84 (3H, s, H-28), 0.83 (3H, s, H-25); GC-MS: $m / z 426$ [15].

$\beta$-Amyrin (7) - White solid (22 mg, 22\%); m.p. 196-198 C; IR $r_{\text {max }} \mathrm{cm}^{-1}: 3445,2932,1636,1227 ;{ }^{1} \mathrm{H}$ NMR $(400 \mathrm{MHz}$, $\left.\mathrm{CDCl}_{3}\right): \delta 5.54(1 \mathrm{H}, \mathrm{dd}, J=3.2,8.0 \mathrm{~Hz}, \mathrm{H}-12), 3.42(1 \mathrm{H}, \mathrm{t}, J$ $=2.8 \mathrm{~Hz}, \mathrm{H}-3), 1.99$ (3H, m, CH, H-5/H-9/H-14), $1.49(20 \mathrm{H}$, m, H-1/H-2/H-6/H-7/H-11/H-15/H-16/H-19/H-21/H-22), 1.10 (3H, s, H-27), 0.95 (9H, s, H-24/H-26/H-28), $0.92(6 \mathrm{H}$, s, H-29/H-30), 0.88 (3H, s, H-23), 0.83 (3H, s, H-25); 3); EIMS: $m / z 426$ [16].

Macaranga species have shown a lot of potential as natural medicines as they had been used in traditional medicine by native people from respective places. Therefore, a lot of studies have been conducted on various species to prove their medicinal values. In this study, the biological activities which had been reported are antioxidant, $\alpha$-glucosidase inhibitory and antibacterial activities. Total phenolic content was determined using Folin-Ciocalteau's reagent adapted to a 96-well microplate where gallic acid was used as the standard. The results were expressed as mg gallic acid per gram of extract (mg GAE/g) [23]. Table 1 displays the results of total phenolic contents of all extracts. The $\mathrm{MeOH}$ extract of $M$. hosei showed the highest phenolic content (347.7 mg GAE/g) compared to other extracts. The results of total phenolic content obtained from these two extracts correlated with the antioxidant values resulted in free radical scavenging assay against DPPH. This proved the theory that the phenolic compounds may be present in these extracts which helps in enhancing the antioxidant values [23]. From observation, the total phenolic content of extracts increased with the increasing polarity of solvents. The summary of the $\mathrm{SC}_{50}$ values of extracts against DPPH are presented in Table 1. Among all the extracts from two Macaranga species, the $\mathrm{MeOH}$ extract from $M$. hosei displayed the most significant free radical scavenging activity with $\mathrm{SC}_{50}$ value of $25.8 \mathrm{ppm}$. This is followed by the $\mathrm{MeOH}$ extract of $M$. constricta and the $\mathrm{CHCl}_{3}$ extract of $M$. hosei with $\mathrm{SC}_{50}$ values of 26.7 and 31.4 ppm respectively. The high antioxidant activity displayed by these two extracts might be resulted from the presence of phenolic compounds with high number of hydroxyl groups which can donate hydrogens to stabilize the free radicals [23].

a-Glucosidase inhibitory assay was conducted on all extracts of the Macaranga species. In this assay, the inhibitors present in the body suppressed $\alpha$-glucosidase enzyme and inhibited the release of glucose from the carbohydrate which later reduced the postprandial blood glucose level [24]. The assay was determined spectrophotometrically at $405 \mathrm{~nm}$ in a 96-well microtiter plate. The results of the a-glucosidase inhibition activity of the tested samples are summarized in Table 1. The results showed that all crude extracts exhibited positive result as a-glucosidase inhibitors with petroleum ether extract of $M$. hosei exhibited the most potent activity with $\mathrm{IC}_{50} 25.3 \mathrm{ppm}$. It was followed closely by the $\mathrm{MeOH}$ and $\mathrm{CHCl}_{3}$ extracts of the same species each with $\mathrm{IC}_{50} 36.0$ and $44.2 \mathrm{ppm}$. The PE extract of $M$. constricta exhibited the least inhibition activity with $\mathrm{IC}_{50} 237.6 \mathrm{ppm}$. The high inhibition activity of $M$. hosei extracts may be contributed by the presence of high content of phenolic compounds which were

Table 1. Percentage yield, antioxidant and a-glucosidase inhibitory activity of Macaranga species

\begin{tabular}{|c|c|c|c|c|c|}
\hline Species & Extract & Yield (g, \%) & $\begin{array}{c}\text { TPC } \\
\text { (mg GAE/g) }\end{array}$ & $\begin{array}{c}\mathrm{DPPH} \\
\mathrm{SC}_{50}(\mathrm{ppm})\end{array}$ & $\begin{array}{c}\text { a-Glucosidase } \\
\text { IC }_{50}(\mathrm{ppm})\end{array}$ \\
\hline \multirow[t]{3}{*}{ M. hosei } & $\mathrm{PE}$ & $12.0 \mathrm{~g}, 2.4 \%$ & $164.8 \pm 16.8$ & $73.1 \pm 30.4$ & 25.3 \\
\hline & $\mathrm{CHCl}_{3}$ & $0.3 \mathrm{~g}, 0.1 \%$ & $198.9 \pm 29.9$ & $31.4 \pm 4.2$ & 44.2 \\
\hline & $\mathrm{MeOH}$ & $17.5 \mathrm{~g}, 3.5 \%$ & $347.7 \pm 9.2$ & $25.8 \pm 1.7$ & 36.0 \\
\hline \multirow[t]{3}{*}{ M. constricta } & PE & $7.3 \mathrm{~g}, 1.5 \%$ & $148.4 \pm 3.7$ & $>1000$ & 237.6 \\
\hline & $\mathrm{CHCl}_{3}$ & $4.9 \mathrm{~g}, 1.0 \%$ & $152.4 \pm 22.0$ & $178.6 \pm 12.8$ & 56.1 \\
\hline & $\mathrm{MeOH}$ & $30.0 \mathrm{~g}, 6.0 \%$ & $316.7 \pm 47.7$ & $26.7 \pm 1.5$ & 91.9 \\
\hline
\end{tabular}

$\mathrm{PE}$ - petroleum ether; GAE - gallic aicd equivalent; Standards - Ascorbic acid $\left(\mathrm{SC}_{50} 8.9 \pm 0.2 \mathrm{ppm}\right)$; Butylated hydroxyl toluene $\left(\mathrm{SC}_{50} 15.3 \pm\right.$ $0.6 \mathrm{ppm}) ;$ Quercetin $\left(\mathrm{IC}_{50} 4.5 \mathrm{ppm}\right)$; Acarbose $\left(\mathrm{IC}_{50} 12.6 \mathrm{ppm}\right)$ 
<smiles>C=C(C)[C@H]1CC[C@]2(C)CC[C@]3(C)C(CCCC4[C@@]5(C)CCC(=O)C(C)(C)C5CC[C@]43C)C12</smiles>

(1)
(2)<smiles>COc1ccc(-c2cc(=O)c3c(O)c(OC)c(OC)cc3o2)cc1</smiles>

(3)
(4)

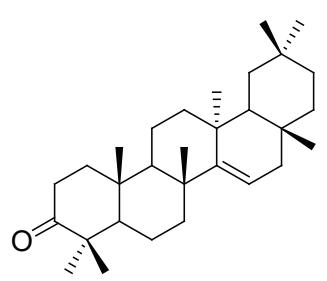

(5)

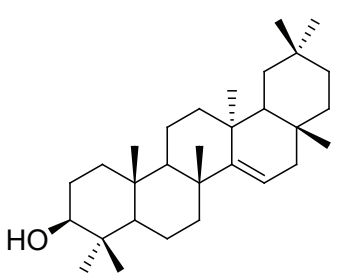

(6)

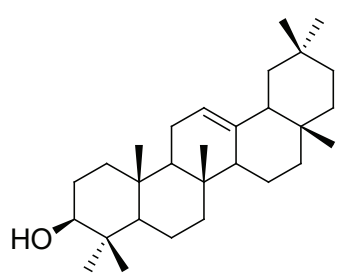

(7)

Figure 1. Chemical structures of compounds isolated from Macaranga species

failed to be isolated in this study. Phenolic compounds can be oxidized to phenolate ions or quinones, thus, they are able to block or enhance responsible's enzymes for the digestion of carbohydrate [25].

The antibacterial assay was conducted on the extracts using micro dilution method. None of the extracts were effective against B. subtilis, S. aureus and E. coli. Meanwhile, all the isolated compounds displayed no inhibition activity against all three bacterial strains. This suggested that all compounds do not have antibacterial properties which may correlate with weak activity observed on the extracts. Previous studies revealed the isolation of triterpenoids derivatives with significant antibacterial properties identified as arjulonic acid and asiatic acid from Syzygium guineense [26]. The presence of hydroxyl group at C-23 and carboxylic acid substituent in the structure was the determining factors which aids in the antibacterial properties of these compounds against variety of pathogenic bacteria [26]. Thus, the absence of these acid substituents in the structure of triterpenoids (5), (6), and (7) may explains the absence of inhibition towards the tested bacterial strains. A study conducted on Chromolaena species by Taleb-Contini et al., [27] had revealed the isolation of some flavonoids derivatives with significant antibacterial properties. It is revealed that flavonoids with hydroxyl groups at C-7, C-3' and C-4' positions gave positive antibacterial tests. This result correlated with the weak antibacterial activity possessed by compound (3) where it has only methoxyl groups at position C-7 and C-4' which may decrease the antibacterial property.

\section{Conclusion}

In conclusion, very little phytochemical work has been done on the genus Macaranga. An overview of the literature search indicated that only twenty six Macaranga species have been investigated phytochemically as compared to about 300 plant species known from this genus. Therefore, more phytochemical studies are needed to validate the claimed of their traditional uses.

\section{Materials and Methods}

\subsection{General experimental procedures}

Two types of extraction methods were applied which were cold extraction and soxhlet extraction techniques. All the chemicals were analytical grade. Petroleum ether (PE), $n$-hexane, diethyl ether $\left(\mathrm{Et}_{2} \mathrm{O}\right)$, dichloromethane $\left(\mathrm{CH}_{2} \mathrm{Cl}_{2}\right)$, chloroform $\left(\mathrm{CHCl}_{3}\right)$, ethyl acetate (EtOAc) and methanol $(\mathrm{MeOH})$ were the solvents used in the extraction and chromatographic process. Preliminary phytochemical screening was conducted on all extracts. Evaporation of the solvents from the crude extracts was carried out using Eyela Rotary Evaporator N-1000 model. Thin Layer Chromatography (TLC) analysis was done on precoated silica gel aluminium sheets with Merck Silica Gel $60 \mathrm{~F}_{254}$ with the thickness of $0.2 \mathrm{~mm}$ as the stationary phase. The spots on the TLC plates were visualized by UV at $254 \mathrm{~nm}$ and $365 \mathrm{~nm}$ before sprayed with vanillin sulphuric acid reagent. Further fractionation and purification of the crude extracts were conducted using vacuum liquid chromatography (VLC) 
and column chromatography $(\mathrm{CC})$. Merck silica gel $\left(\mathrm{SiO}_{2}\right)$ of 230-400 Mesh was used as the stationary phase for VLC while $\mathrm{SiO}_{2}$ of 70-230 Mesh was the packing material for CC. Melting points were measured using a hot stage Gallen apparatus and were uncorrected. Infrared Spectroscopy (IR) was recorded on a Perkin Elmer FTIR Frontier spectrophotometer with Universal ATR sampling accessory. ${ }^{1} \mathrm{H}$ and ${ }^{13} \mathrm{C}$ NMR spectra were recorded on Bruker Avance 400 and $100 \mathrm{MHz}$ spectrometer using deuterated solvent $\mathrm{CDCl}_{3}$ or stated otherwise. Mass spectral data were acquired by GC-MS and Bruker Mass Spectrometry Services from National University Singapore. Gas chromatography (GC) was performed using a Hewlett Packard HP6890 series II A fitted with Ultra-I column. GC-MS analyses were carried out using a Hewlett Packard Model 5890A gas chromatograph and a Hewlett Packard Model 5989A mass spectrometer.

\subsection{Plant materials}

The fresh leaves of M. hosei (HTBP 290) and M. constricta (HTBP 1121) were collected from Terengganu in 2007 and identified by Mr. Ahmad Zainuddin Ibrahim. The voucher specimens were deposited at the herbarium of Universiti Kebangsaan Malaysia.

\subsection{Extraction and isolation}

The dried leaves of $M$. hosei (500 g) were ground into powder and extracted with soxhlet apparatus using $\mathrm{PE}(5 \mathrm{~L}), \mathrm{CHCl}_{3}$ $(5 \mathrm{~L})$ and $\mathrm{MeOH}(5 \mathrm{~L})$ consecutively for $16 \mathrm{~h}$. The PE extracts $(11.0 \mathrm{~g})$ was subjected to VLC ( $n$-hexane: $\left.\mathrm{Et}_{2} \mathrm{O}\right)$ on $\mathrm{SiO}_{2} 230$ 400 mesh to give five major fractions, MHP 1-5. The MHP 2 fraction $(55.0 \mathrm{mg})$ was purified using CC $\left(n\right.$-hexane: $\left.\mathrm{Et}_{2} \mathrm{O}\right)$ in stepwise gradient. Fractions with similar TLC profiles were combined to obtain five major fractions MHP 2A-2E. Fraction MHP 2E was further purified using $\mathrm{SiO}_{2} \mathrm{CC}$ ( $n$-hexane: $\mathrm{Et}_{2} \mathrm{O}$ ) and fractions 1-19 were combined to afford lupenone (1). Fractions MHP $4(4.0 \mathrm{~g})$ was purified by $\mathrm{CC}$ over $\mathrm{SiO}_{2}$ to afford a total of 400 fractions collected and combined to give seven subfractions, MHP 4A-G. Subfraction MHP 4A $(0.5 \mathrm{~g})$ was further purified by CC $\left(n\right.$-hexane: $\left.\mathrm{Et}_{2} \mathrm{O}\right)$ to yield $\beta$-sitostenone (2). MHP 4B (13.7 mg) was purified by CC ( $n$-hexane: $\mathrm{Et}_{2} \mathrm{O}$ ) in stepwise gradient to yield 240 fractions. Fractions 101-141 were combined and concentrated to give 5-hydroxy-7,4'-dimethoxyflavone (3). The $\mathrm{CHCl}_{3}$ extract (0.3 g) was subjected to $\mathrm{CC}$ on $\mathrm{SiO}_{2}\left(n\right.$-hexane: $\left.\mathrm{Et}_{2} \mathrm{O}\right)$ in increasing polarity to give 180 fractions. Further purifications on the fractions failed to give a pure compound. The $\mathrm{MeOH}$ extract
$(17.45 \mathrm{~g})$ was subjected to VLC ( $n$-hexane:EtOAc:acetone) in increasing polarity to give five fractions, MHM $1-5$. Fraction MHM $2(0.1 \mathrm{~g})$ was then subjected to $\mathrm{CC}$ ( $n$-hexane: $\mathrm{CHCl}_{3}$ ) to give a total of 100 fractions which were combined to give five major fractions labeled as MHM 2A-E. Subfraction MHM $2 \mathrm{~A}(0.04 \mathrm{~g})$ undergone further purification over CC on $\mathrm{SiO}_{2}$ with $n$-hexane-EtOAc as the eluents mixture. Fractions 1-95 from MHM 2-A were combined and concentrated to give 5-hydroxy-6,7,4'-trimethoxyflavone (4).

The dried leaves of $M$. constricta (500 g) were ground into powder and extracted with soxhlet apparatus using PE (5 L), $\mathrm{CHCl}_{3}(5 \mathrm{~L})$ and $\mathrm{MeOH}(5 \mathrm{~L})$ consecutively for $16 \mathrm{~h}$. The PE extracts (MCP) (7.0 g) was subjected to $\mathrm{VLC}$ on $\mathrm{SiO}_{2}(230$ 400 mesh) with $n$-hexane and $\mathrm{Et}_{2} \mathrm{O}$ in stepwise gradient were used as the eluents to give twelve major fractions labeled as MCP1-12. Upon removal of solvent, fraction MCP 3 (0.14 g) was recrystallized with $n$-hexane repetitively to yield taraxerone (5). Fraction MCP 7 (0.1 g) was washed with $n$-hexane repetitively to give $\beta$-amyrin (7). Fraction MCP 12 (1.2 g) was subjected to $\mathrm{CC}$ on $\mathrm{SiO}_{2}$ (70-230 mesh), using gradient elution of $n$-hexane: $\mathrm{Et}_{2} \mathrm{O}$ to give a total of 245 fractions. Fractions were combined based on TLC profile to give eight new fractions labeled as MCP 12-A to MCP $12-\mathrm{H}$ where fraction MCP 12-C (26.6 mg) yielded taraxerol (6). The $\mathrm{CHCl}_{3}$ extracts (MCC) (4.5 g) was fractionated on VLC using using $n$-hexane and $\mathrm{Et}_{2} \mathrm{O}$ in increasing polarity as the eluent mixture. TLC screening was conducted on the fractions obtained and similar profiles of TLC was combined into five major fractions and labeled as MCC 1-5. Fraction MCC 2 was purified repetitively on CC using $n$-hexane and $\mathrm{Et}_{2} \mathrm{O}$ eluents in stepwise gradient. A single spot was obtained from this fraction and ${ }^{1} \mathrm{H}$ NMR analysis on the sample showed that it was similar compound to compound (6). The $\mathrm{MeOH}$ extracts (MCM) (25.0 g) was fractionated using $n$-hexane: $\mathrm{Et}_{2} \mathrm{O}: \mathrm{EtOAc}$ on VLC to give four major fractions labeled as MCM 1-4. However, purification failed to isolate a pure compound from these fractions.

\subsection{Biological activities}

Antioxidant: 1,1-diphenyl-2-picrylhydrazyl (DPPH), ascorbic acid, gallic acid, and butylated hydroxytoluene (BHT) were obtained from Sigma-Aldrich (Germany). Analytical grade methanol, ethanol and dimethylsulfoxide (DMSO) were purchased from Merck (Germany). a-Glucosidase: Dimethyl sulfoxide (DMSO), p-nitrophenyl$\alpha$-D-glucopyranose (PNPG), a-glucosidase (Maltase) enzyme, acarbose and quercetin hydrate were purchased from 
Sigma-Aldrich (Germany). Potassium phosphate monobasic $\left(\mathrm{KH}_{2} \mathrm{PO}_{4}\right)$ and sodium carbonate $\left(\mathrm{Na}_{2} \mathrm{CO}_{3}\right)$ were purchased from Merck (Germany). Antibacterial: Nutrient agar (NA), nutrient broth (NB), and streptomycin sulphate were purchased from Oxoid (Italy). All tested microorganisms were purchased from Mutiara Scientific (Malaysia).

\subsection{Antioxidant activity}

\subsubsection{Total phenolic content (TPC)}

Total phenolic content was carried out according to the method described by Kassim et al. [28] with minor modifications. The stock solution of $1000 \mathrm{ppm}$ of the tested sample and standard Gallic acid was prepared. Sodium carbonate solution was prepared by dissolving $3 \mathrm{~g}$ of sodium carbonate with $50 \mathrm{~mL}$ of distilled water. 40 $\mu \mathrm{L}$ of stock solution was added into the first two rows (A and $\mathrm{B}$ ) before double manifold dilution was conducted by mixing the solution with $40 \mu \mathrm{L}$ of $\mathrm{MeOH}$ from row B to $\mathrm{H}$. Then, $20 \mu \mathrm{L}$ of Follin-Ciocaltaeu's reagent was mixed into the solution and it was incubated for 5 mins in dark condition. After incubation, $80 \mu \mathrm{L}$ of $\mathrm{Na}_{2} \mathrm{CO}_{3}$ solution and $60 \mu \mathrm{L}$ of distilled water were added. The tested solution was then incubated for $90 \mathrm{~min}$ in dark condition before it was measured at $760 \mathrm{~nm}$. A calibration graph of standard gallic acid was constructed. Total phenolic content was expressed as mg Gallic acid (GAE) per gram of extract.

\subsubsection{DPPH Radical scavenging assay}

The DPPH free radical scavenging assay was conducted based on method reported by Kassim et al. [28] with minor modifications. $2000 \mu \mathrm{M}$ of DPPH reagent was prepared by dissolving $0.8 \mathrm{mg}$ of $\mathrm{DPPH}$ in $1 \mathrm{~mL}$ of $\mathrm{MeOH}$. The stock solution of the tested samples was prepared by dissolving it with $\mathrm{MeOH}$ to obtain concentration of $1000 \mathrm{ppm} .170 \mu \mathrm{L}$ of stock solution was then added to the first two rows (A and B) of the 96-well microplate. Double manifold dilution was performed on row $\mathrm{B}$ to row $\mathrm{H}$ by adding $170 \mu \mathrm{L}$ of $\mathrm{MeOH}$ into them. This step was conducted so that, we can have a series of concentration ranging from 1000 to $7.81 \mathrm{ppm}$. After that, $30 \mu \mathrm{L}$ of DPPH reagent was added into all rows before incubated for 30 mins in dark condition. The absorbance of the tested solution was measured at $517 \mathrm{~nm}$ using Epoch microplate reader. The percentage of scavenging of DPPH was calculated using the following formula;

$\mathrm{I} \%=\left[\mathrm{A}_{\text {blank }}-\mathrm{A}_{\text {sample }} / \mathrm{A}_{\text {blank }}\right] \times 100$

\section{6 $\alpha$-Glucosidase Inhibitory Activity}

The assay was performed following the methods of Mediani et al. [29] with slight modifications. In brief, $10 \mu \mathrm{L}$ of sample with concentration of $100,80,60,40,20,10$ and $1 \mu \mathrm{M}$ in $5 \%$ DMSO was added to $130 \mu \mathrm{L}$ of potassium diphosphate buffer (30 mM, pH 6.5) and $10 \mu \mathrm{L} \alpha$-glucosidase enzyme (Maltase - $2 \mathrm{U} / \mathrm{mL}$ ) in the 96 -well plate. The mixture was incubated for $20 \mathrm{~min}$. at $37^{\circ} \mathrm{C}$ before addition of $50 \mu \mathrm{L}$ of $p$-nitrophenyl- $\alpha$ - $D$-glucopyranoside ( $p$-NPG) $(1 \mathrm{mM})$. The mixture was incubated for another $20 \mathrm{~min}$. at $37^{\circ} \mathrm{C}$ in the dark. The reaction was quenched by adding $50 \mu \mathrm{L}$ of sodium carbonate solution $(0.2 \mathrm{M})$ and the absorbance was recorded at $405 \mathrm{~nm}$ by measuring the quantity of $p$-nitrophenol released from $p$-NPG. Acarbose was employed as the positive control for this assay. The percentage of inhibition was calculated as a percentage relative to a control.

$\left[\mathrm{I} \%=\mathrm{A}_{\text {Control }}-\left(\mathrm{A}_{\text {Sample }}-\mathrm{A}_{\text {Blank sample }}\right) / \mathrm{A}_{\text {Control }} \times 100\right]$

where $A_{\text {Sample }}$ is the absorbance of the reaction mixture of the test sample, $A_{\text {Blank sample }}$ is the absorbance of the reaction mixture containing all reagents except enzyme and $\mathrm{A}_{\text {Control }}$ is the absorbance of the reaction mixture containing all reagents except the test sample.

\subsection{Antibacterial activity}

The test microorganisms, Bacillus subtilis (ATCC6633), Staphylococcus aureus (ATCC29737) and Escherichia coli (ATCC10536) were used. The strains were grown on Nutrient broth (NB) for the bacteria. The minimal inhibitory concentration (MIC) was determined by broth micro dilution method using 96-well microplates [30]. The inocula of the microbial strains were prepared from $24 \mathrm{~h}$ broth cultures and McFarland standard turbidity of suspensions was adjusted to 0.5 . Sample $(1 \mathrm{mg})$ was dissolved in DMSO $(1 \mathrm{~mL})$ to get $1000 \mu \mathrm{g} / \mathrm{mL}$ stock solution. A number of wells were reserved in each plate for positive and negative controls. The mixture of samples and sterile broth $(100 \mu \mathrm{L})$ were transferred to each well in order to obtain a twofold serial dilution of the stock samples (concentration of 1000, 500, 250, 125, 62.5, 31.3, 15.63 and $7.8 \mu \mathrm{g} / \mathrm{mL})$. The inoculated bacteria $(100 \mu \mathrm{L})$ were added to each well. The final volume in each well was 200 $\mu \mathrm{L}$. Strepyomysin sulfate was used as positive controls for bacterial. Plates were incubated at $37^{\circ} \mathrm{C}$ for $24 \mathrm{~h}$. Microbial growth was indicated by the turbidity and the presence of pellet at the bottom of the well. 


\section{Acknowledgements}

The authors would like to thank the Ministry of Higher Education (MOHE) Malaysia for the research grant and financial support under Grant University Project (GUP) QJ130000.7126.02H30 and Department of Chemistry, Faculty of Science, Universiti Teknologi Malaysia for the NMR facilities.

\section{Authorship contributions}

Concept - W.M.N.H.W.S., N.Z.A.R., F.A.; Design W.M.N.H.W.S., N.Z.A.R., F.A.; Supervision - F.A.; Resource - F.A.; Materials - F.A.; Data Collection and/ or Processing - W.M.N.H.W.S., N.Z.A.R.; Analysis and/or Interpretation - W.M.N.H.W.S., N.Z.A.R., F.A.; Literature Search - W.M.N.H.W.S., N.Z.A.R.; Writing - W.M.N.H.W.S., N.Z.A.R..; Critical Reviews - W.M.N.H.W.S., N.Z.A.R., F.A.

\section{Conflict of interest}

The authors declared no conflict of interest.

\section{References}

1. Ju A, Feldhaar H, Feldmeyer B, Fiala B. Chemical composition of leaf volatiles in Macaranga species (Euphorbiaceae) and their potential role as olfactory cues in host-localization of foundress queens of specific ant partners. Biochem Syst Ecol 2006; 34: 97-113.

2. Lim TY, Lim YY, Yule CM. Evaluation of antioxidant, antibacterial and anti-tyrosinase activities of Four Macaranga species. Food Chem 2009; 114: 594-9.

3. Davies SJ, Palmiotto PA, Ashton PS, Lee HS, Lafrankie JV. Comparative ecology of 11 sympatric species of Macaranga in Borneo: Tree Distribution in relation to horizontal and vertical resource heterogeneity. J Ecol 1998; 86: 662-73.

4. Heil M, Fiala B, Kaiser W, Linsenmair KE. Chemical contents of Macaranga food bodies: Adaptations to their role in ant attraction and nutrition. Funct Ecol 1998; 12: 117-22.

5. Baker JA. Notes on the biology of Macaranga species. Gardens Bull 1934; 8: 63-74.

6. Isely $\mathrm{D}$. Investigations in seed classification by family characteristics. Res Bull 1947; 350-2.

7. Whitmore TC, Airy Shaw HK. Studies in Macaranga: IV: New and notable records for Malaya. Royal Bot Gards 1971; 25: 237-42.

8. Davies SJ. Systematics of Macaranga sect. Pachystemon and Pruinosae (Euphorbiaceae). Harvard Papers Bot 2001; 6: 371448.

9. Marliana E, Tjahjandarie TS, Tanjung M. Isoprenylated flavanone derivatives from Macaranga hosei King ex Hook.F. Der Pharm Lett 2015; 7: 153-6.
10. Venkata C, Prakash S, Prakash I. Isolation and structural characterization of lupane triterpenes from Polypodium Vulgare. Res J Pharm Sci 2012; 1: 23-7.

11. Prachayasittikul S, Suphapong S, Worachartcheewan A, Lawung R, Ruchirawat S, Prachayasittikul V. Bioactive metabolites from Spilanthes acmella Murr. Molecules 2009; 14: 850-67.

12. Eswaraiah MC, Elumalai A. Isolation of phytoconstituents from the stems of Mussaenda erythrophylla. Pelagia Res Lib 2011; 2: 132-42.

13. Ayatollahi SA, Shojaii A, Kobarfard F, Mohammadzadeh M, Choudhary MI. Two flavones from Salvia leriaefolia. Iranian J Pharm Res 2009; 8:179-84.

14. Koay YC, Wong KC, Osman H, Eldeen I, Asmawi MZ. Chemical constituents and biological activities of Strobilanthes crispus L. Rec Nat Prod 2013; 7: 59-64.

15. Tareq FS, Sohrab H, Uddin AMS, Afroz F, Hasan CM. Phytochemical studies on the leaves of Xylia dolabriformis. J Pharm Sci 2009; 52: 171-2.

16. Ogwuche CE, Amupitan JO, Ndukwel G, Ayo RG. Isolation and biological activity of the triterpene $\beta$-amyrin from the aerial plant parts of Maesobotrya barteri (Baill). Med Chem 2014; 4: 729-33.

17. Phommart S, Sutthivaiyakit P, Chimnoi N, Ruchirawat S, Sutthivaiyakit S. Constituents of the leaves of Macaranga tanarius. J Nat Prod 2005; 68: 927-30.

18. Zakaria I, Ahmat N, Jaafar FM, Widyawaruyanti A. Flavonoids with antiplasmodial and cytotoxic activities of Macaranga triloba. Fitoterapia 2012; 83: 968-72.

19. Sultana S, Ilyas M. Chromenoflavones from Macaranga indica. Phytochemistry 1986; 25: 953-4.

20. Hnawia E, Thoison O, Guéritte-Voegelein F, Bourret D, Sévenet T. A geranyl substituted flavonol from Macaranga vedeliana. Phytochemistry 1990; 29: 2367-8.

21. Sutthivaiyakit $S$, Unganont $S$, Sutthivaiyakit $P$, Suksamrarn A. Diterpenylated and prenylated flavonoids from Macaranga denticulata. Tetrahedron 2002; 58: 3619-22.

22. Kawakami S, Harinantenaina L, Matsunami K, Otsuka H, Shinzato T, Takeda Y. Macaflavanones A-G, prenylated flavanones from the leaves of Macaranga tanarius. J Nat Prod 2008; 71: 1872-6.

23. Zhang Y, Shen Y, Zhu Y, Xu Z. Assessment of the correlations between reducing power, scavenging DPPH activity and antilipidoxidation capability of phenolic antioxidants. LWT Food Sci Technol 2015; 63: 569-74.

24. Andrew O, Yusuf S, Jangabe LM, Lawal BS, Aliyu AA. a-Glucosidase inhibitory potential of selected anti-diabetic plants used in North-Western Nigeria. J Med Pl Res 2013; 7: 2010-8.

25. Lee SY, Mediani A, Ashikin N, Azliana ABS, Abas F. Antioxidant and $\alpha$-glucosidase inhibitory activities of the leaf and stem of selected traditional medicinal plants. Int Food Res J 2014; 21: 165-72.

26. Djoukeng JD, Abou-mansour E, Tabacchi R, Tapondjou AL, Bouda H, Lontsi D. Antibacterial triterpenes from Syzygium guineense (Myrtaceae). J Ethnopharmacol 2005; 101: 283-6.

27. Taleb-Contini SH, Salvador MJ, Watanabe E, Ito IY. Antimicrobial activity of flavonoids and steroids Isolated 
from two Chromolaena species. Braz J Pharm Sci 2003; 39: 403-8.

28. Kassim NK, Rahmani M, Ismail A, Sukari MA, Gwendoline CLE, Nasir NM, Awang K. Antioxidant activity-guided separation of coumarins and lignan from Melicope glabra (Rutaceae). Food Chem 2013; 139: 87-92.

29. Mediani LSY, Ashikin NAH, Azliana ABS, Abas F. Antioxidant and $\alpha$-glucosidase inhibitory activities of the leaf and stem of selected traditional medicinal plants. Int Food Res J 2014; 21 : 165-72.

30. Salleh WMNHW, Ahmad F, Khong HY. Chemical compositions and biological activities of the essential oils of Beilschmiedia madang Blume (Lauraceae). Arch Pharm Res 2015; 38: 485-93. 